\title{
THE AURIFEROUS SUBMARINE FANS SANDSTONES OF THE IONIAN ZONE (EPIRUS, GREECE)
}

\author{
Manoutsoglou E. ${ }^{\text {, Batsalas A. }}{ }^{1}$, Stamboliadis E. ${ }^{1}$, Pantelaki O. ${ }^{1}$, Vakalas I. ${ }^{2}$ \\ and Zelilidis A. ${ }^{2}$ \\ ${ }^{1}$ Technical University of Crete, Department of Mineral Resources Engineering, University Campus \\ 73100 Chania,emanout@mred.tuc.gr \\ ${ }^{2}$ University of Patras, Department of Geology, Patras 26110, Greece
}

\begin{abstract}
During recent decades many studies have be done on the rocks that developed in the area of Western Greece and especially in Epirus, known in geoscientific literature as Ionian Zone of External Hellenides. These rocks have undergone geological research (basic geological mapping, research for hydrocarbons, metals and inert materials) and exploitation (inert materials). Recently, within the sedimentary succession of the Ionian zone submarine fans, in the region of Peta-Kompoti, in the prefecture of Arta, have been identified positions where sedimentary gold is present. Recently, positions where sedimentary gold is present, within the sedimentary rocks of the submarine fans, in the region of Peta-Kompoti, prefecture of Arta, have been identified. For the continuation and the practical application of these positive results, it was necessary to obtain a documented reference of geological parameters. After a series of new sampling and detailed analysis of the samples, this work presents the detected gold concentrations, illustrates the limits of grouping areas of interest as well as delineating and illustrating palaeogeographic factors that have contributed to the creation of gold-bearing formations. The highest gold concentration found was in the Ta Bouma sequence. The observation of constant indications of high gold values above background that suddenly increase in certain places up to $260 \mathrm{ppb}$, leads to the conclusion that in the broader area and within locations with equivalent formations procedure, there could be gold pockets of exploitable concentrations.
\end{abstract}

Key words: gold exploration, gold concentration, gold-bearing formations, flysch, Ionianzone, Epirus, Western Greece.

\section{Introduction}

Different hydrocarbon zones are distributed over wide areas on both margins of the Adriatic and Ionian Seas. Major episodes, of paleogeographically widespread source-bed deposition, occurred in the Mesozoic and Cenozoic. Cenozoic rocks, of fine marly to coarse terrigenous source, accumulated preferentially in foreland basins, e.g. the Ionian Zone (External Hellenides). This basin is suitable for hydrocarbon exploration (Zelilidis et al., 2003). The exploration, which began 50 years ago, has brought to light an abundance of information on the structure and palaeogeographic evolution of the basin. Furthermore, a considerable amount of stratigraphic data has been accreted, which constitutes the basis for the evaluation of the palaeoenvironmental setting, the depositional evolution of the basin (I.G.S.R./I.F.P., 1966), and creation of geological maps of western Greece 1:50000 by the Institute of 
Geology and Mineral Exploration (IGME).

However, none of the investigations conducted so far has provided long-term data on the existence of mineralization in the wider region. Recently, there have been identified positions, within the sedimentary rocks of the submarine fans in the region of Peta-Kompoti, prefecture of Arta, where sedimentary gold is present. In these rocks gold occurs as free metal in granules of 5-1000 microns in size (Pantelaki, 2001; Stamboliadis et al., 2002; Stamboliadis et al., 2003).

For the continuation and the practical application of these positive results, it was necessary to obtain a documented reference of geological parameters. These would indicate the places, entrenched with gold concentrations above background values, in the thick and spread sequence of submarine fans. Based on a series of new sampling and analysis of the samples, this work presents the detected gold concentrations and illustrates the palaeogeographic factors that have contributed to the creation of gold-bearing formations.

\section{Geological setting}

The geological area under investigation belongs to the Ionian zone of Western Greece. After the accumulation of predominantly calcareous sediments and during the Mesozoic and the PaleoceneEocene, the uplift and the subsequent erosion of the cordillera, situated east of the Ionian Zone, caused clastic deposition in the active Pindos Foreland Basin, associated with Mesohellenic and Neohellenic tectonic cycles (Fleury, 1980; Jacobshagen, 1986). The proximal clastics of the internal areas are thicker and coarser than the distal ones of the middle or even external parts. Accordingly, submarine fans sedimentation, mainly clays and sandstones with conglomeratic beds, started earlier in the east than in the west (Bizon, 1967), and earlier in the north than in the south (Avramidis et al., 2002). The western border of the Ionian trough is the slope of the Apulian Platform, known as the Pre-Apulian Zone, and was not covered by submarine fan deposits. The carbonatic-pelitic sedimentation on this platform continued up to the Upper Miocene (I.G.S.R./I.F.P., 1966; BP, 1971). According to Richter $(1974,1976)$ the internal, middle and external parts of the Ionian Basin are separated by intrabasinal highs. This arrangement of the sea-floor was the main factor that controlled the flow direction and the extension of the clastic terrigenous turbidity currents (Avramidis \& Zelilidis, 2001; Avramidis et al., 2002).

This long year's research work has created many views on the distribution of submarine fan deposits in the three sub-basins, as well on the lithostratigraphic nomenclature reflected in the geological maps of Western Greece.According to palaeocurrent direction and sedimentlogical data, the sediments of the basin originate mainly from the east. The two-stage rotation, suffered by the broader Helladic area, has played an important role in the evolution of the basin; according to palaeomagnetic data (see Avramidis, 1999).

Apart from the classical theories, related to the spatial correlation of lithostratigraphic units of the submarine fans, recent theories have appeared. These theories extended not only in the age correlation of submarine fans, (Leigh, 1991; Bellas et al., 1995; Bellas, 1997), but also in the distribution of the different facies (Avramidis, 1999; Vakalas, 2003) and in the direct relationship between locations of origin and evolution of palaeocurrents. All the above allows the interpretation of a genetic model of the overall sequence of the Pindos foreland submarine fan deposits.

\section{Experimental Procedures}

Cyanidation is the usual method for the recovery of finely disseminated and liberated metallic gold. According to the procedure used the ore sample is crushed and ground to liberate gold. One $\mathrm{kg}$ of the ground sample is mixed with 3 lt of water in a glass bottle. The following reagents are also added in 
the pulp: 7,5 $\mathrm{gr} \mathrm{Ca}(\mathrm{OH})_{2}$ for the adjustment of $\mathrm{pH}$ in the desirable level, ( $\left.\mathrm{pH} 11\right), 4,5 \mathrm{gr} \mathrm{NaCN}$, that corresponds to concentration $1500 \mathrm{ppm} \mathrm{NaCN}$ in the leaching solution or 4,5 $\mathrm{kg} \mathrm{NaCN}$ per ton of ore and $50 \mathrm{gr}$ active carbon $(+1.7 \mathrm{~mm})$, for the adsorption of the dissolved gold. The bottle is rolled for 48 hours. At the end of the reaction period the pulp is screened at $1.00 \mathrm{~mm}$, to remove the active carbon. The loaded active carbon and the remaining barren ore are fire assayed for gold. According to this method a certain quantity of the sample to be assayed, $30 \mathrm{~g}$ from mineral samples and $1 \mathrm{~g}$ from active carbon samples, are mixed with the appropriate quantities of $\mathrm{Na}_{2} \mathrm{CO}_{3}, \mathrm{PbO}, \mathrm{CaCO}_{3}, \mathrm{SiO}_{2}$, $\mathrm{Na}_{2} \mathrm{O} \cdot 2 \mathrm{~B}_{2} \mathrm{O}_{3} \cdot 10 \mathrm{H}_{2} \mathrm{O}$ etc. and fired at about $950{ }^{\circ} \mathrm{C}$ to obtain a lead button that is separated from the slag after cooling. The lead button undergoes cupellation at $1050{ }^{\circ} \mathrm{C}$ in order to obtain the gold nugget that also contains any silver $(\mathrm{Ag})$ present in the ore. The nugget is consequently dissolved in aqua regia and assayed for gold by atomic absorption spectrometry. In any cyanidation test the gold content of the feed is the sum of the gold quantity distributed in the active carbon and the non dissolved quantity in the residue. Obviously the gold absorbed by the active carbon is the recoverable gold, the nonrecoverable gold exists either finely disseminated, non liberated metallic gold, which can be recovered by further grinding, or is in the form of refractory gold, in the lattice of sulphide minerals mainly pyrite and arsenopyrite, that can be recovered only after destruction of the host minerals.

\section{Sampling and Results}

Three sampling sets were conducted in the major area of the Arta prefecture, where all the lithostratigraphic units of the Internal Ionian Zone submarine fans exist, as indicated in the geological map of Peta, scale 1:50000. In this map the submarine fan sequence developed above the Palaeogene limestone of the Ionian Zone and consists of the Peta sandstones, the Araxthos marls, the Anemorachi sandstones, and finally the formation of Distrato. In this area the above sequence has a thickness more than four kilometers forming a large synclinal structure. The first sampling set in the area was based on the above initial geological data and eighteen (18) random samples were collected. Only six (6) of the above samples indicated the existence of gold and are presented in Table 1. The rest of the samples had zero gold concentrations.

The above eighteen samples were collected along a natural section in the area of Kompoti (Arta prefecture). Three different sub-environments were identified in this section, presented in Figure 1, and from the bottom to the top they are: a) the outer fan sub-environment b) the inner fan sub-environment and c) a ponted basin sub-environment. Thickness of inner fan deposits is from 150 to $900 \mathrm{~m}$. The appearance of sandstones of facies $\mathrm{C} 2.1$, that are characterized by an upwards decrease of their thickness

Table 1. General description of the first six positive samples.

\begin{tabular}{|c|c|c|}
\hline $\begin{array}{c}\text { Sample } \\
\text { Number }\end{array}$ & Location & $\begin{array}{c}\text { Recoverable Au } \\
\text { (ppb) }\end{array}$ \\
\hline A1 & Turn after Kompoti, lower center of the lence type bank & 263 \\
\hline A2 & Turn after Kompoti, upper center of the lence type bank & 194 \\
\hline A3 & Turn after Kompoti, middle center of the lence type bank. & 4,0 \\
\hline A4 & West side & 9,0 \\
\hline A5 & Center & 49,0 \\
\hline A6 & Upper & 4,0 \\
\hline
\end{tabular}



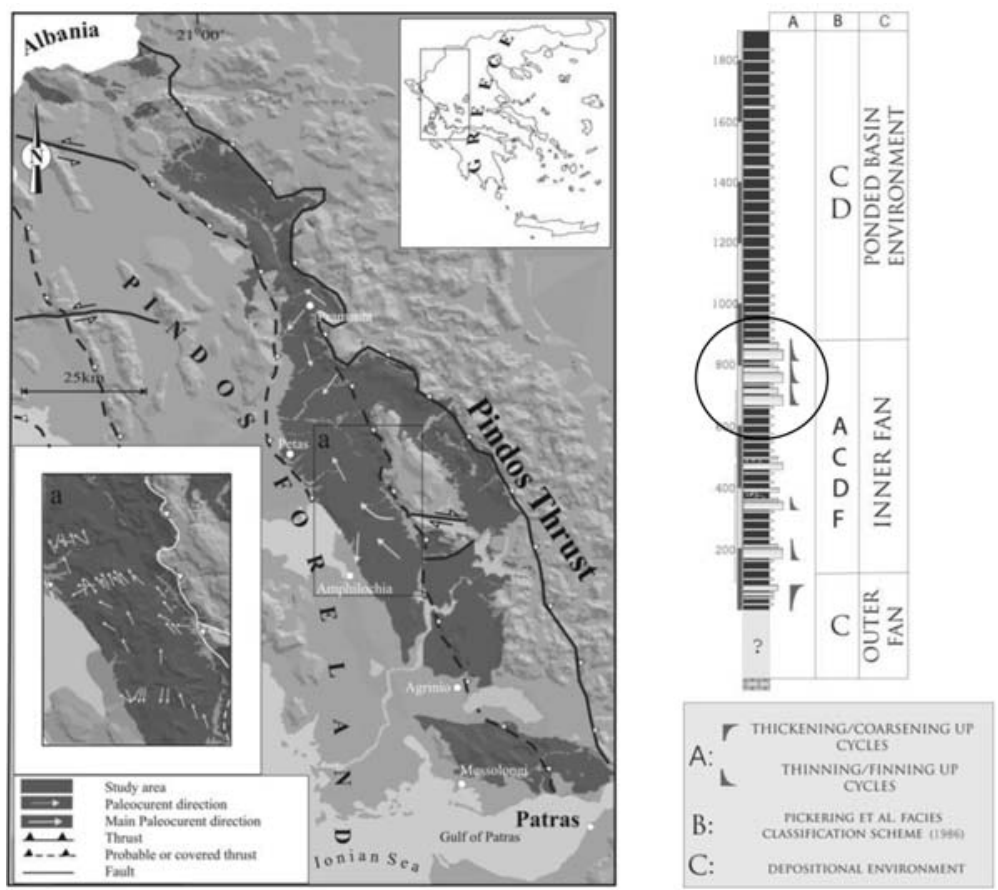

Fig. 1: Palaeocurrent directions in the investigated area. On the right side appears the stratigraphic column of Kompoti section (Vakalas, 2003) and the position of the positive samples 1-6 (cycle).

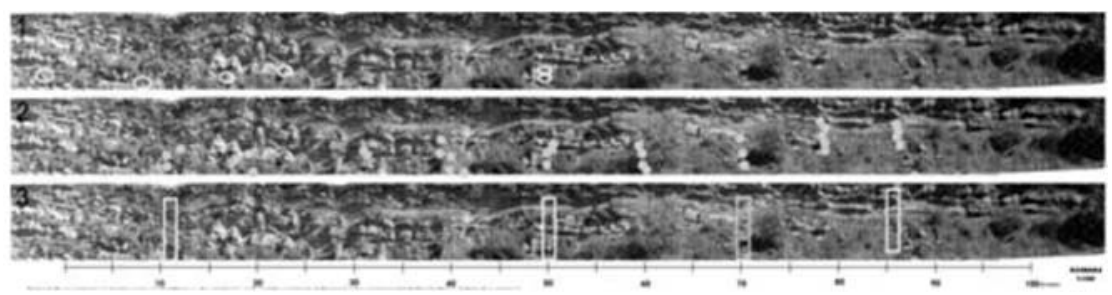

Fig. 2: Panoramic view, showing part of the Kompoti section, with three set sampling area. From top to bottom: first set with 18 samples, second set with 36 samples and third set with 4 samples. The position of the section is shown in Fig. 1. Detail of the profile Kompoti by Vakalas (2003).

and grain size, classifies this facies to a channel environment of the inner fan (Vakalas, 2003).

After investigation of the palaeocurrent directions in the broader area, a differentiation can be detected, in relation to the major palaeocurrent direction. Although the directions further north are towards southsouthwest, in the studied Kompoti area the directions not only changed towards north-northwest but they show also characteristics of this turn, see Figure 1.

After the evaluation of the first sampling set results, it was important to have a second more detailed sampling set in the area, which not only provides the most comprehensive geological information but also focused on the higher gold values in the first random sampling. In the following systematic sampling, 36 samples of about $2 \mathrm{~kg}$ each were collected from successive positions of the section as seeing in Figure 2 . 
Table 2. General description of the second campaign samples.

\begin{tabular}{|c|c|c|}
\hline $\begin{array}{l}\text { Sample } \\
\text { Number }\end{array}$ & Sample location & $\begin{array}{c}\text { Recoverable } \\
\text { Au (ppb) }\end{array}$ \\
\hline B1 & Position $92 \mathrm{~m}$. Base of bank 3. Third bank on the east side $75 \mathrm{~cm}$ thick & 19 \\
\hline B2 & Position $92 \mathrm{~m}$. Top of bank 3. & 19 \\
\hline B3 & Position $92 \mathrm{~m}$. Upper $30 \mathrm{~cm}$ of the clastic sequence. & 15 \\
\hline B4 & $\begin{array}{c}\text { Position } 92 \mathrm{~m} \text {. Base of bank 4, bank thickness } 47 \mathrm{~cm} \text { with intensive evidence } \\
\text { of bioturbation and many plant residues. }\end{array}$ & 14 \\
\hline B5 & Position $80 \mathrm{~m}$. Upper part of the middle clastic sequence between banks 2 and 3 . & 16 \\
\hline B6 & Position $80 \mathrm{~m}$. Base of bank 3 . & 16 \\
\hline B7 & Position $80 \mathrm{~m}$. Top of bank 3 . & 14 \\
\hline B8 & Position $80 \mathrm{~m}$. Middle of clastic zone between banks 3 xaı 4. & 14 \\
\hline B9 & $\begin{array}{c}\text { Position } 80 \mathrm{~m} \text {. Base of bank } 4 \text {, above the clastic sequence that is reduced to } \\
\text { the west (bank } 4 \text { contains many plant residues.) }\end{array}$ & 20 \\
\hline B10 & Position $70 \mathrm{~m}$. Top of bank 1 . Only its roof appears at this point. & 21 \\
\hline B11 & Position $70 \mathrm{~m}$. Bank 2, about $80 \mathrm{~cm}$ thick at this point. & 18 \\
\hline B12 & Position $70 \mathrm{~m}$. Base of bank 3 , about $85 \mathrm{~cm}$ thick at this point. & 17 \\
\hline B13 & $\begin{array}{l}\text { Position } 60 \mathrm{~m} \text {. siltstone below the base of bank 1. the visible thickness below } \\
\text { bank } 1 \text { is } 90 \mathrm{~cm}\end{array}$ & 19 \\
\hline B14 & Position $60 \mathrm{~m}$. Base of bank 1. Thickness at this point $1 \mathrm{~m}$. & 11 \\
\hline B15 & Position $60 \mathrm{~m}$. roof of bank 1 & 17 \\
\hline B16 & Position $60 \mathrm{~m}$. Base of bank 2, thickness of bank 2 at this point $50 \mathrm{~cm}$. & 17 \\
\hline B17 & Position $50 \mathrm{~m}$. Base of bank 1. thickness of bank 1 at this point $115 \mathrm{~cm}$. & 19 \\
\hline B18 & Position $50 \mathrm{~m}$. top of bank 1. & 38 \\
\hline B19 & $\begin{array}{l}\text { Position } 50 \mathrm{~m} \text {. siltstone between banks } 1 \text { and } 2 \text {, the thickness of siltstone be- } \\
\text { tween banks } 2 \text { and } 3 \text { is } 85 \mathrm{~cm} \text {. }\end{array}$ & 6 \\
\hline B20 & Position $50 \mathrm{~m}$. Base of bank 2. & 18 \\
\hline B21 & Position $40 \mathrm{~m}$. siltstone below bank 1. & 9 \\
\hline B22 & Position $40 \mathrm{~m}$. base of bank 1. & 13 \\
\hline B23 & Position $40 \mathrm{~m}$. top of bank 1. & 16 \\
\hline B24 & 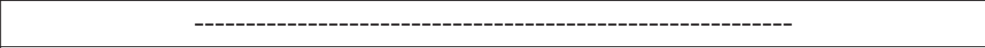 & - \\
\hline B25 & Position $40 \mathrm{~m}$. siltstone between banks 1 and 2 . & 18 \\
\hline B26 & Position 40 m. Base of bank 2. & 17 \\
\hline B27 & Position 30 m. siltstone below bank 1. & 18 \\
\hline B28 & Position 30 m. Base of bank 1. & 18 \\
\hline B29 & Position $30 \mathrm{~m}$. Top of bank 1. & 17 \\
\hline B30 & Position $30 \mathrm{~m}$. siltstone between banks 1 and 2 . & 16 \\
\hline B31 & Position $20 \mathrm{~m}$. Base of bank 0 . & 18 \\
\hline B32 & Position $20 \mathrm{~m}$. Intermediate fine banks. & 15 \\
\hline B33 & Position $20 \mathrm{~m}$. Base of bank 1. & 14 \\
\hline B34 & Position $10 \mathrm{~m}$. siltstone below bank 0 . & 14 \\
\hline B35 & Position 10 m. Bank 0. & 13 \\
\hline B36 & Position $10 \mathrm{~m}$. siltstone between banks 0 and 1 . & 17 \\
\hline
\end{tabular}


The results of the second sampling set are presented in Table 2, while the recoverable gold is presented in Tables 2 and 3.

After the evaluation of the above samples a third sampling set was also conducted in the same area. A total of four larger samples were collected, varying from 12 to $28 \mathrm{~kg}$ each, in a vertical cut of the natural section as showing in Figure 2 as well. The results are presented in Table 3.

Table 3. Recoverable gold of the third sampling set.

\begin{tabular}{|c|c|}
\hline Sample number & Recoverable Au (ppb) \\
\hline C1 & 4.71 \\
\hline C2 & 0.00 \\
\hline C3 & 0.20 \\
\hline C4 & 0.00 \\
\hline
\end{tabular}

Following the evaluation of all samples, eight of them, from the 36 ones of the second set, were ground further finer than $90 \mu \mathrm{m}$. The finely ground samples were treated by cyanidation in order to study the effect of size in the liberation of gold and its recovery. The results of Table 4 show a considerable increase in gold recovery after grinding that indicates a very fine dissemination of gold in the rock environment (Batsalas, 2006).

Table 4. Comparison of recoverable gold between coarse and fine grinding.

\begin{tabular}{|c|c|c|}
\hline A/A & $\begin{array}{c}\text { Coarse sample } \mathbf{- 5 0 0} \boldsymbol{\mu m} \\
\text { Recoverable Au }(\mathbf{p p b})\end{array}$ & $\begin{array}{c}\text { Fine sample } \mathbf{- 9 0} \boldsymbol{\mu m} \\
\text { Recoverable Au } \mathbf{p p b})\end{array}$ \\
\hline B2 & 19 & 26 \\
\hline B9 & 20 & 20 \\
\hline B10 & 21 & 26 \\
\hline B11 & 18 & 21 \\
\hline B13 & 19 & 22 \\
\hline B17 & 19 & 23 \\
\hline B27 & 18 & 21 \\
\hline B28 & 18 & 22.6 \\
\hline Average & 19.0 & 22 \\
\hline
\end{tabular}

\section{Discussion and Results}

The classical methodology followed for gold search is based on the statistical processing of a large number of data (Keppie et al., 1986; Nekrasov, 1996). As is appears from the presentation of the obtained data, although the gold values show a non uniform distribution (nugget effect) however, both in the first random sampling set, as well as in the next geologically controlled ones, gold values are 
well above the expected background. The average gold values vary in the different types of rocks. Clay sediments of deep sea have an average gold content of $3.0 \mathrm{ppb}$ (Crocket, 1993). Carbonaceous sediments have the lowest gold content than any other sedimentary type of rock. It is reminded that most of the gold in all the word has been recovered from sedimentary rocks. As a whole the conglomerates, the sandstones and the siltstones give an average gold content of $8.1 \mathrm{ppb}$ (Crocket, 1993).

Generally, there are a large number of geological models explaining gold depositions. Some research workers accept that the generation of gold depositions is related to large masses of rocks through reactions between fluids and existing rocks deep in the earth crust, while others give emphasis to the importance of relatively limited rock generating groups of rocks that make the so called "mother rocks" that accumulated gold above the ordinary values. It is therefore important to know the average content of gold in different types of rocks and at the same time the gold content that suggests a probable ore generation. Areas, with a gold content about 10000 times greater than the back ground, can be characterized as gold ores. Nevertheless, gold concentrations of some tens ppb may indicate procedures of formation of a gold deposition (Crocket, 1993).

The mass flows are very common in mountainous as well as in sea environments. The mechanics of mass flow on the earth surface and below sea level differ in many aspects and it is important to notice that probability of conservation of the depositions formed by mass flows under the sea is much higher than the one of terrestrial environments. However, under sea formations are difficult to be studied and they have rarely been observed on their genesis. May be this is the reason why there is such a debate in literature concerning these procedures. Very often, the depositions of undersea mass flows have larger dimensions than on the earth surface and can fill with sediments a great part of sea basins. Even more, the lake and sea gravitational flows of sediments are very often developed into turbidity currents that create such structures called "turbidites".

Since many gravitational flows of sediments change from uniform into fully turbulent systems, a precise correspondence of the natural flows to ideal ones is usually very difficult. It is only in depositions of gravitational flows that have been conserved where their internal structure and sedimentary structures may register the manner of the final deposition but they cannot fully reveal the probably variable character of the flow during its transportation from an inclined to the basin of deposition, (Middleton \& Hampton, 1976; Middleton, 1993; Einsele, 1996; 2000).

In accordance to the complicated and over-discussed procedures of gold accumulation in sedimentary deposits, in the case of turbidic currents, which create an environment of dispersion and classification at the same time, one could extrapolate the general rules of heavy minerals enrichment in aqueous currents. Both in aqueous turbidic currents, turbulence are the main mechanism that moves the sediments.

A coarse grain of quartz has the same settling velocity as a smaller grain of a heavier mineral. These two grains although they are different in size they are hydraulically equivalent. I the case of a narrow pass where the velocity is high there is no deposition of material. When the pass is broadening the velocity of the water or turbidic current slows down and the hydraulically heavier minerals start to settle while the lighter ones move further apart. Generally, the high density of gold allows its deposition under complicated natural processes in all sedimentary environments. In all cases it is the gravity, the type of liquid as well as the type of flow that determine the dynamic of the probable accumulations (Eyles, 1995).

The specific area of sampling, confirmed only on inner fan deposits (the lower stratigraphic unit of the studied section) are sediments accumulated by turbidic currents. In a wide flow environment, no other flow type is capable to result in a concentration of gold, because of the great difference in the density of gold. The highest gold concentration found was in the Ta Bouma sequence (Bouma 1962). 
The observation of constant indications of high gold values above background that suddenly increase in certain places up to $260 \mathrm{ppb}$, leads to the conclusion that in the broader area and within locations with equivalent formations procedure, there could be gold pockets of exploitable concentrations. Accordingly the area that has been specified with the above criteria can be enlarged to a wider border. Gold exists as free metal and is not in the lattice of another mineral (refractory gold) but is very finely disseminated. This is better supported from the fact that finer grinding of the samples has resulted in better liberation and hence a better recovery of the precious metal.

A series of paper (Leigh \& Hartley 1992, Faupl et al. 1996, Faupl et al. 1998, Avramidis \& Zelilidis, 2001) provides evidence for the origin of the material that fueled the turbidity currents. Apart from the erosion material of rocks of the Pindos nappe, also materials derived from erosion of internal zones nappes, transported over the Pindos nappe, were involved. Although they may be several assumptions, for the moment there is no evidence to indicate the provenance of gold bearing materials.

\section{Acknowledgments}

The authors E. Manoutsoglou and A. Batsalas would like to acknowledge the contribution of ELKE, Technical University of Crete, in providing financial support necessary to their research work and travelling for sampling.

\section{References}

Avramidis, P., Zelilidis, A., 2001. The nature of deep-marine sedimentation and palaeocurrent trends as evidence of Pindos foreland basin fill conditions. Episodes, 24 (4), 252-256.

Avramidis, P., 1999. Environments of sedimentation tertiary formations of the basin KlematiasParamythias, of Epirus. Probable generation and deposition of hydrocarbons in these formations. $P h D$ Thesis, University of Patras, Geology department, Patras, 1-165, (in greek).

Avramidis, P., Zelilidis, A., Vakalas, I., Kontopoulos, N., 2002. Interaction between tectonic activity and eustatic sea-level changes in the Pindos and Mesohellenic Basins, NW Greece: basin evolution and hydrocarbon potential. Journal of Petroleum Geology, 25 (1), 53-82.

Batsalas, A., 2006. Geological parameters and concentrations of sedimentary gold in sandstones of flysch. Post graduate thesis, Technical University of Crete, Department of Mineral resources Engineering, Chania, 1-125, (in greek).

Bellas, S., 1997. Calcareous nannofossils of the Tertiary Flysch (Post Eocene to Early Miocene) of the Ionian Zone in Epirus, NW-Greece: Taxonomy and Biostratigraphical correlations. PhD Thesis, Freie Universität Berlin, Berlin, 1-173.

Bellas, S., Mertmann, D., Manutsoglu, E., Bartholdy, J., Frydas, D., 1995. The Oligocene Argyrotopos Profile in the external Ionian basin (Epirus, Greece), Microfacies \& Microfossils. Facies, 33, 107-120.

Bizon G., 1967. Contribution à la connaissance des foraminiféres planctoniques d' Epire et des iles Ioniennes. Technip ed. Paris, 1-142.

Bouma, A.H., 1962. Sedimentology of some flysch deposits. (Elsevier), Amsterdam, 1-168.

British Petroleum Co. Ltd. (B.P.) 1971. The geological results of petroleum exploration in western Greece. Institute for Geology and Subsurface Research, Special report 10, Athens.

Crocket, J.H. 1993. Distribution of gold in the Earth's crust. In: Foster, R.P., (Editor), Gold Metallogeny and Exploration, 1-36, (Chapman \& Hall), London - Madras.

Einsele, G., 1996. Event deposits: the role of sediment supply and relative sea-level changes - overview. Sediment Geology, 104, (Special issue), 11-37. 
Einsele, G., 2000. Sedimentary basins: evolution, facies, and sediment budget. (Springer-Verlag), Berlin - Heidelberg, 1-792.

Eyles, N., 1995. Characteristics and origin of coarse gold in Late Pleistocene sediments of the Cariboo placer mining district, British Columbia, Canada. Sedimentary Geology, 95, 69-95.

Faupl, P., Pavlopoulos, A., Wagreich M. and Migiros, G., 1996. Pre-Tertiary blueschist terrains in the Hellenides: evidence from detrital minerals of flysch successions, Terra Nova, 8, 186-190.

Faupl, P., Pavlopoulos, A. and Migiros, G., 1998. On the provenance of flysch deposits in the External Hellenides of mainland Greece: results from the heavy mineral studies. Geol. Mag., 135 (3), 421-442.

Fleury, J.-J., 1980. Les zones de Gevrovo-Tripolitza et du Pinde-Olonos (Grece Continentale et Peloponnese du Nord). Evolution d'une platforme et une bassin dans le cadre alpin, Soc. Geol. Nord, 4, 1-651.

I.F.P./I.G.S.R. 1966. “Etude géologique de l’Epire (Grèce nord-occidentale). Paris, 1-306.

Jenkins, D.A.L., 1972. Structural development of western Greece. Bull. Am. Ass. Petrl. Geol., 56, 128-149.

Jacobshagen, V., 1986. Geologie von Griechenland. (Borntraeger), Berlin - Stuttgart, 1-363.

Keppie, D., Boyle, R.W., Haynes, S.J., 1986. Turbidite-hosted gold deposits. Geological Association of Canada, Special Paper 32, 1-186.

Leigh, S., 1991. The sedimentary evolution of Pindos foreland basin western Greece. PhD Thesis, University of Wales, Cardiff, 1-181.

Leigh, S. and Hartley A.J. 1992. Mega-debris flow deposits from the Oligo-Miocene Pindos foreland basin, western mainland Greece: implications for transport mechanisms in ancient deep marine basins, Sedimentology, 39, 1003-1012.

Middleton, G.V., Hampton, M.A., 1976. Subaqueous sediment transport and deposition by gravity flows. In: Stanley DJ, Swift DJP (eds) Marine sediment transport and environmental management, (Willey), New York, 197-218.

Middleton, G.V., 1993. Sediment deposition from turbidity currents. Annu. Rev. Earth Planet Sci., 21, 89-114.

Nekrasov, I.Y., 1996. Geochemistry, Mineralogy and Genesis of Gold Deposits. A.A. Balkema/Rotterdam/Brookfield, 1-329.

Pantelaki, O., 2001. Investigation of the flysh of Ionian Zone. Graduate thesis, Technical University of Crete, Department of Mineral Resources Engineering, Chania, 1-124, (in greek).

Pavlopoulos, A., 1983. Contribution to the geological study of the flysch of Makrynoros (Akarnania). PhD Thesis, University of Thessaloniki, Faculty of Sciences, Thessaloniki, 1-100, (in greek).

Richter, D., 1974. - Die paläogeographische und Geotektonische Bedentung der Gavrovo - Tripolis Zone auf dem Peloponnes (Griechenland). N. Jb. Geo. Palaont. Abh., 145, I, 96-128.

Richter, D., 1976. Das Flysch-Stadium der Helleniden-Ein Überblick. Zeitschrift der Deutschen Geologischen Gesellschaft, 127, 467-483.

Stamboliadis E., Pantelaki O., Manutsoglu E., 2002. Environmentally friendly methods for gold recovery. - Proceedings of the International Conference «Protection and Restoration of the Environment VI» Skiathos, 43-48.

Stamboliadis E., Manutsoglu E., Pantelaki O., 2003. Development in gold equipment and their use in Greece. - Proceedings of the International Conference «Sustainable Development Indicators in the Mineral Industries» Milos, 329-334.

Vakalas, I., 2003. Development of the foreland basins of Western Greece. PhD Thesis, University of Patras, Geology department, Patras, 1-365, (in greek).

Zelilidis A., Piper D.J.W., Vakalas J., Avramidis, P. \& Getsos, K. 2003: Oil and gas plays in Albania: do equivalent plays exist in Greece? - Journal of Petroleum Geology, 26 (1), 29-48. 